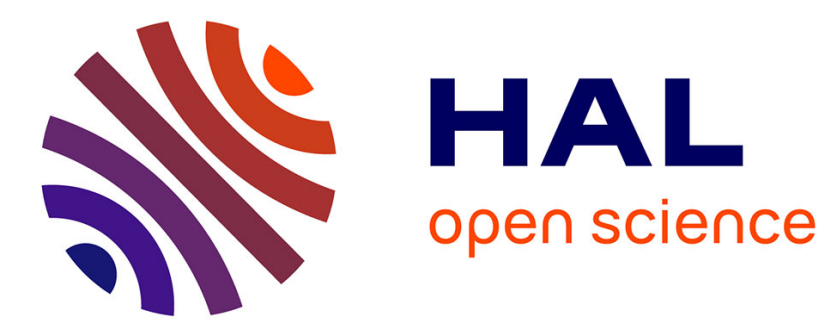

\title{
Temperature thresholds related to flight of Dendroctonus frontalis Zimm. (Col.: Scolytidae)
}

William A. Thompson, John C. Moser

\section{To cite this version:}

William A. Thompson, John C. Moser. Temperature thresholds related to flight of Dendroctonus frontalis Zimm. (Col. : Scolytidae). Agronomie, 1986, 6 (10), pp.905-910. hal-00884838

\section{HAL Id: hal-00884838 \\ https://hal.science/hal-00884838}

Submitted on 1 Jan 1986

HAL is a multi-disciplinary open access archive for the deposit and dissemination of scientific research documents, whether they are published or not. The documents may come from teaching and research institutions in France or abroad, or from public or private research centers.
L'archive ouverte pluridisciplinaire HAL, est destinée au dépôt et à la diffusion de documents scientifiques de niveau recherche, publiés ou non, émanant des établissements d'enseignement et de recherche français ou étrangers, des laboratoires publics ou privés. 


\title{
Temperature thresholds related to flight of Den- droctonus frontalis Zimm. (Col. : Scolytidae)
}

\author{
William A. THOMPSON (*) (') \& John C. MOSER \\ U.S. Department of Agriculture, Forest Service, Pineville, Louisiana, U.S.A. 71360 \\ (*) Appalachian Environmental Laboratory, University of Maryland, Frostburg, Maryland, U.S.A. 21532
} dies. Solar insolation may explain these discrepancies.

Additional key words : insolation, flight, Dendroctonus frontalis.

Chez D. frontalis, on a observé respectivement des températures minimales, optimum, et maximales de vol de $6,7^{\circ} \mathrm{C}, 27,0^{\circ} \mathrm{C}$ et $36,7^{\circ} \mathrm{C}$. Les seuils sont estimés à $5,6^{\circ} \mathrm{C}$ et $38,0^{\circ} \mathrm{C}$. Le minimum de $6,7^{\circ} \mathrm{C}$ est la température de vol la plus basse jamais rapportée chez un Scolytide. Ce minimum est de $7,8^{\circ} \mathrm{C}$ plus bas que les estimations antérieures faites à partir des études de terrain et de $15,3{ }^{\circ} \mathrm{C}$ plus bas que les estimations antérieures de laboratoire. L'insolation peut expliquer ces désaccords.

Additional key words : insolation, essaimage, Dendroctonus frontalis.

\section{INTRODUCTION}

Temperature ranges for scolytid flight have been reported for numerous species (ATKINS \& MCMULLEN, 1960 ; BAKKE, 1968 ; MCCAMBRIDGE, 1971). The majority of these reports document minimum temperature thresholds, with far fewer listing optimum and maximum thresholds. Reports for minimum thresholds have been based either on data from field trapping or on laboratory studies. Figures for field trapping are almost always lower, presumably because of the influence of solar insolation (not insulation) (RUDINSKY, 1962 ; GEER et al., 1981).

We report new and refined data here on minimum and maximum flight thresholds for the southern pine beetle (SPB), Dendroctonus frontalis Zimm., based on data from field trapping. The lower flight threshold from SPB field studies is generally assumed to be about $14.4{ }^{\circ} \mathrm{C}$ (THATCHER, 1967 FRANKLIN, 1970 ; KINN, 1978 ; MOSER \& DELL, 1979 ; 1980).

(1) Present address : Division of Forest Research, CSIRO, Yarralumla ACT 2600 , Australia.
However, laboratory studies of SPB flight by WHITE \& FRANKLIN (1976) indicated that the minimum flight temperature may be closer to $22{ }^{\circ} \mathrm{C}$. GEER et al., 1981 suggested this discrepancy was due to the warming effects of solar insolation in the field.

Although field data from MOSER \& DELL (1979; 1980) supported the $14.4^{\circ} \mathrm{C}$ figure, it was suspected that the threshold might be even lower. The data from the 1979 and 1980 studies were based on semi-weekly and weekly trap collections. Hence, only the highest daily maximum temperature during the collection period could be recorded as the "flight" temperature, because the trap catch did not show on which date any particular beetle had flown. The study, reported here involved daily trap collections, and, therefore, allowed full use of the daily maximum temperature records.

Existing research contains no concrete statements about optimum flight temperature for SPB or any other scolytid. MOSER \& DELL $(1979 ; 1980)$ give an equation for daily catches at selected temperatures from $10-26{ }^{\circ} \mathrm{C}$, where numbers of flying beetles steadily increased with temperature. But they found 
no optimum or peak temperature and noted no sign of reduced beetle flight at the highest temperature encountered $\left(33.9^{\circ} \mathrm{C}\right)$. WHITE \& FRANKLIN (1976) proposed $35^{\circ} \mathrm{C}$ as the maximum flight temperature threshold.

\section{MATERIALS AND METHODS}

Data were gathered daily by methods of MOSER \& BROWNE (1978) at 2 natural pine stands in the Kisatchie National Forest : Bentley, LA, from September 1979 through December 1980 and Camp Livingston, LA, near Pineville, from February 1979 through December 1980. Traps were baited with the SPB pheromone Frontalure, and suspended $4 \mathrm{~m}$ high against $1 \times 30 \times 400 \mathrm{~cm}$ plywood stakes. For each site the number of SPB caught in traps, maximum and minimum air temperature, and amount of rainfall were recorded daily. The Bentley data were collected from an active SPB infestation until its collapse in June 1980. Five traps were placed about $9 \mathrm{~m}$ apart in a line in advance of the forward edge of newly infested trees. The traps were moved forward as the "front" advanced. This period will be referred to as the "outbreak" phase. Thereafter, there were no active trees at the Bentley site. This later phase will be referred to as the "post-outbreak" phase. No actively infested trees appeared at the Livingston site during the sample period. At this site, traps were also spaced $9 \mathrm{~m}$ apart and never moved because no active infestation occurred. The site contained 6 traps from February 1979 through July 1979 and then 8 traps from August 1979 through December 1980.

For analysis of flight activity at extreme temperatures, the data were pooled. Original measurements were made in Fahrenheit to the nearest degree, and transformed to Celsius prior to the data analysis.

\section{RESULTS}

Analysis of variance was performed to compare differences in SPB capture rate between sites (Bentley and Livingston), between sampling periods (February 1979 - June 1980 and July 1980 - December 1980), and between temperatures. There was an active spot at the Bentley site in the first period, but not in the second. The Livingston site never had any active spots. Three temperature ranges were compared: $0-15{ }^{\circ} \mathrm{C}, 15-30{ }^{\circ} \mathrm{C}$, and $30-38{ }^{\circ} \mathrm{C}$. Based upon prior studies, these ranges corresponded to : "too cold to fly", "normal flight temperatures", and "too hot to fly".

Table 1 presents average numbers of SPB/trap/day \pm one standard deviation, for each site, period and temperature range. Table 2 presents statistical comparisons between sites, between periods, and between temperature ranges. Differences between sites were significant only during the outbreak period for the middle and upper temperature ranges. In contrast, differences between periods were significant at both sites for both middle and upper temperature ranges. Finally, as expected, differences between temperature ranges were always significant. In summary we found that : 1) at above $15^{\circ} \mathrm{C}$, more SPB were caught at the outbreak site during the outbreak ; 2) following the outbreak, numbers of SPB caught did not vary between sites ; 3) below $15^{\circ} \mathrm{C}$, the few SPB caught did not vary in numbers between sites or between outbreak and postoutbreak periods ; 4) at all times, numbers of SPB caught were higher for the middle temperature range than for either of the extreme ranges.

A second analysis of variance was done using the same site and period categories, but treating each Celsius degree as a separate temperature treatment (table 3). In general, we found that variation in capture rate within the 3 temperature ranges was small compared to the variation between temperature ranges. $R^{2}$ values over the entire temperature range went from a minimum of 0.118 to a maximum of 0.248 (depending upon site and period). Thus, even when outbreak status is considered, maximum daily temperature alone provides only a fair predictor of daily SPB capture rate.

A major objective of this study was to characterize the relationship between flight and temperature at the extremes of the temperature range over which SPB fly. As shown above, we could pool the data for the $0-15{ }^{\circ} \mathrm{C}$ range. In addition, we chose to pool the data for the other temperature ranges as well. While we recognized that no firm quantitative statements could be made from the pooled data for the upper 2 temperature ranges, we felt that a clearer qualitative picture of changing SPB flight activity with temperature could best be obtained this way.

TABLE 1

Average numbers of SPB/trap/day + one standard deviation. Sample size for each combination of site, period, and temperature range is in parentheses.

Nombre moven de scolytes capturés par piège et par jour et écart-type. La taille de chaque échantillon pour un site, une période et une gamme de température donnés est indiquée entre parenthèses.

\begin{tabular}{|c|c|c|c|c|}
\hline \multicolumn{5}{|c|}{ Temperature $\left({ }^{\circ} \mathrm{C}\right)$} \\
\hline Site & Period & $0-15$ & $15-30$ & $30-38$ \\
\hline \multirow[t]{2}{*}{ Bent. } & Out. & $0.16+0.71(69)$ & $6.23+7.30(183)$ & $3.09+4.14$ \\
\hline & Post. & $0.00+0.00(16)$ & $0.05+0.14(56)$ & $0.01+0.05(66)$ \\
\hline \multirow[t]{2}{*}{ Liv. } & Out. & $0.02+0.08(59)$ & $0.62+0.79(278)$ & $0.76+1.13(196)$ \\
\hline & Post. & $0.00+0.00(21)$ & $0.08+0.16$ & $0.01+0.06(64)$ \\
\hline
\end{tabular}


TABLE 2

Differences in SPB/trap/day between : (a) sites, for each of 3 temperature ranges and 2 time periods;

(b) time periods, for each of 3 temperature ranges and 2 sites; (c) temperature ranges, for each of 2 time periods and 2 sites.

Significance levels (one-way ANOVA) : NS = not significant $;{ }^{*}=p<0.1 ;{ }^{* *}=p<0.01 ;{ }^{* * *}=p<0.001$.

Différences dans le nombre de scolytes capturés par piège et par jour entre : a) sites, pour chacune des 3 séries de températures

et 2 périodes de temps; $b$ ) périodes de temps, pour chacune des 3 séries de température et 2 sites; c) séries de températures,

pour chacune des 2 périodes de temps et 2 sites. Seuils de signification (analyse de variance unifactorielle) : NS = non significatif ;

$$
*^{*}=p<0,1 ; * *=p<0,01 ; * * *=p<0,001
$$

\begin{tabular}{|c|c|c|c|c|c|}
\hline \multicolumn{6}{|c|}{ Température $\left({ }^{\circ} \mathrm{C}\right)$} \\
\hline & & & $0-15$ & $15-30$ & $30-38$ \\
\hline \multirow{2}{*}{ a. } & \multirow{2}{*}{ Period } & Outbreak & NS & $* * *$ & $* * *$ \\
\hline & & Postoutbreak & NS & NS & NS \\
\hline \multicolumn{6}{|c|}{ Temperature $\left({ }^{\circ} \mathrm{C}\right)$} \\
\hline \multirow{4}{*}{ b. } & \multirow{5}{*}{ Site } & & $0-15$ & $15-30$ & $30-38$ \\
\hline & & Bentley & NS & $* * *$ & $* * *$ \\
\hline & & Livingston & NS & $* * *$ & $* * *$ \\
\hline & & & Peri & & \\
\hline \multirow[b]{3}{*}{ c. } & & & & Outbreak & Postoutbreak \\
\hline & \multirow{2}{*}{ Site } & Bentley & & $* * *$ & * \\
\hline & & Livingston & & $* * *$ & $* *$ \\
\hline
\end{tabular}

TABLE 3

Differences in numbers of $S P B /$ trap/day between temperatures (by single degrees Celsius) for each temperature range, site, and time period. Significance levels (one-way (ANOVA) : NS = not significant ; ${ }^{*}=p<0.1 ;{ }^{* *}=p<0.01 ;{ }^{* * *}=p<0.001$.

Différences dans les nombres de scolytes capturés par piège et par jour entre températures, pour chaque série de températures, site et période de temps.

Seuils de signification (analyse de variance unifactorielle) : NS $=$ non significatif $;{ }^{*}=p<0,1 ;{ }^{* *}=p<0,01 ;{ }^{* * *}=p<0,001$.

\begin{tabular}{|c|c|c|c|c|c|}
\hline \multicolumn{6}{|c|}{ Temperature $\left({ }^{\circ} \mathrm{C}\right)$} \\
\hline Site & Period & $0-15$ & $15-30$ & $30-38$ & $0-38$ \\
\hline \multirow[t]{2}{*}{ Bent. } & Out. & NS & NS & NS & $* * *$ \\
\hline & Post. & NS & NS & NS & NS \\
\hline \multirow[t]{2}{*}{ Liv. } & Out. & NS & $* * *$ & NS & NS \\
\hline & Post. & NS & NS & NS & NS \\
\hline
\end{tabular}

Data were grouped by maximum daily temperature (T), giving the average number of SPB/trap/day at each recorded temperature (fig. 1). These values will henceforth be denoted $\mathrm{S}(\mathrm{T})$. $\mathrm{T}$ ranged from 0 to $38.3^{\circ} \mathrm{C}$, with SPB being captured from $6.7^{\circ} \mathrm{C}$ to 36. ${ }^{\circ} \mathrm{C}$. The data show a clear, steady upward trend in $\mathrm{S}(\mathrm{T})$ to about $25^{\circ} \mathrm{C}$ and a declining trend after $30{ }^{\circ} \mathrm{C}$, with peak activity at $27^{\circ} \mathrm{C}$.

Since the number of observations at extreme temperatures was small (especially for high temperatures), it is possible that SPB flight occurs below $6.7^{\circ} \mathrm{C}$ and/or above $36.7^{\circ} \mathrm{C}$. By fitting a regression equation to these data, we can estimate minimum and maximum flight temperatures. After transforming the data to a logarithmic scale $(0.1$ was added to $S(T)$ to avoid taking logarithms of zero values), the best fit obtained was a linear equation in $\mathrm{T}$ and the absolute value of $T-27\left(R^{2}=0.793, p<0.0001\right)$. In the original units, the equation is
This equation projects a minimum flight temperature of $5.6^{\circ} \mathrm{C}$ and a maximum flight temperature of $38.0{ }^{\circ} \mathrm{C}$ (fig. 1).

We also examined a second measure of SPB flight activity, the percentage of days on which SPB were caught at each temperature (denoted $P(T)$ ). Similar to the data on numbers of SPB/trap/day, P(T) has an increasing and then decreasing trend as the temperature rises. These data and the best fit regression equation are shown in figure 2 . The equation (with $\mathrm{R}^{2}=0.767, \mathrm{p} .<0.0001$ ) is

$$
\mathrm{P}(\mathrm{T})=117.7653-1.3120 \mathrm{~T}-4.9956|\mathrm{~T}-27|
$$

This equation projects a minimum flight temperature of $4.6^{\circ} \mathrm{C}$ maximum flight temperature of $41.2{ }^{\circ} \mathrm{C}$, and peak activity at $27^{\circ} \mathrm{C}$.

Because the regression equation is linear in $\mathrm{T}$, it is sensitive to the number of observations with no captures at temperatures below the minimum flight threshold. Yet further observations at temperatures 


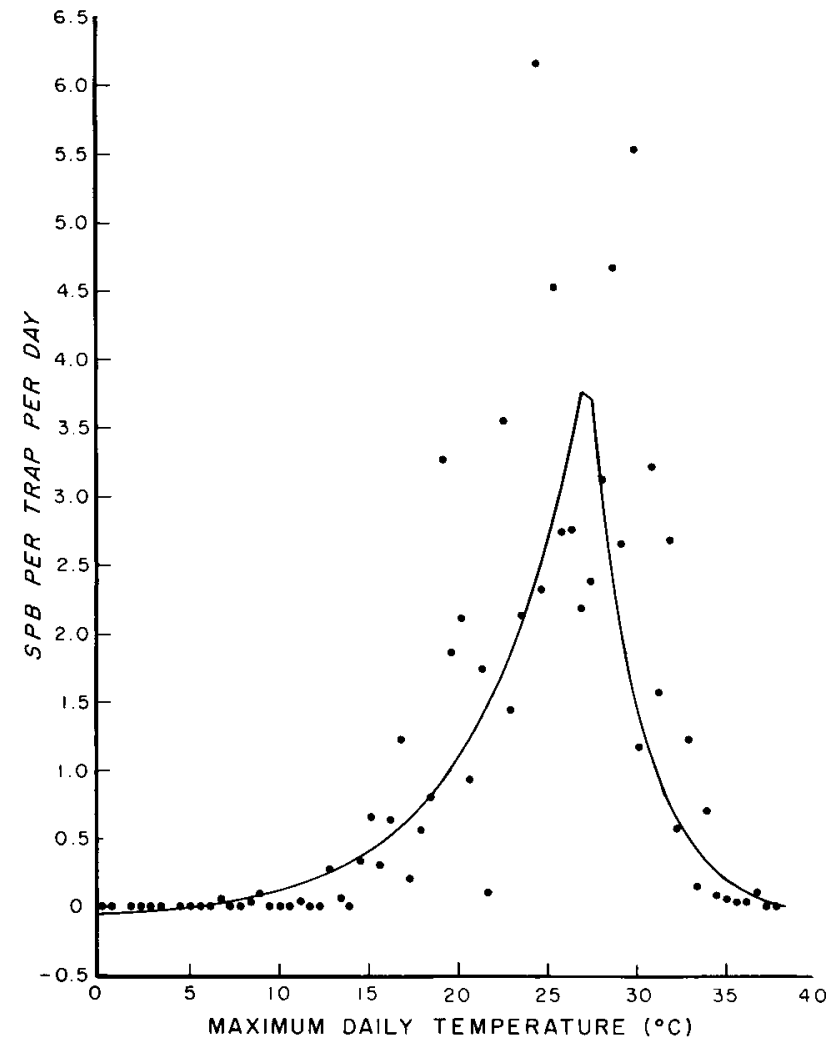

Figure 1

Regression curve fit to average number of $S P B /$ trap/day for each recorded maximum daily temperature (see eqn. 1).

Courbe de régression des nombres moyens de scolytes capturés par piège et par jour par rapport aux maxima quotidiens de température (équation I).

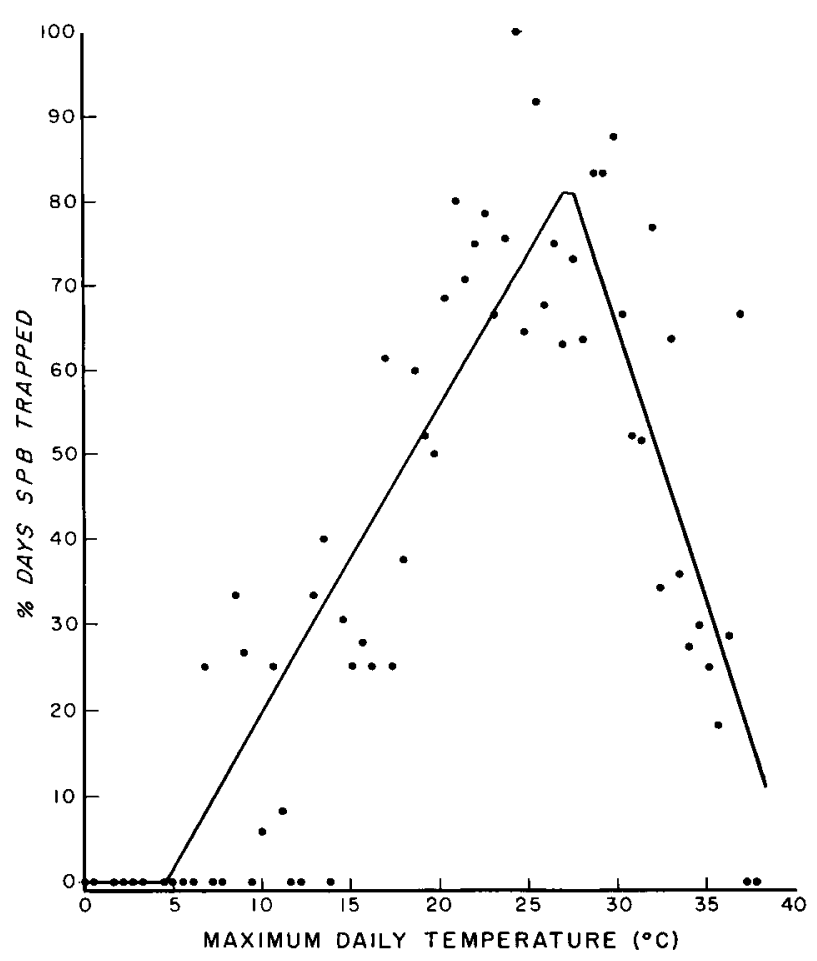

Figure 2

Percent of days on which SPB were captured at each recorded maximum daily temperature and regression line (see eqn. 2).

Pourcentage de jours pendant lesquels les scolytes furent capturés pour chaque maximum quotidien de température et droite de régression (équation 2). below the true minimum flight temperature should not influence our estimate of that temperature. We can get a fair projection, however, of an upper bound on the minimum flight temperature by deleting all observations with $\mathrm{T}$ below the lowest temperature with nonzero value for $P(T)$. Doing so gives the value $6.5^{\circ} \mathrm{C}$. A similar argument can be made for the maximum flight temperature, yielding a revised estimate of $40.9^{\circ} \mathrm{C}$.

\section{DISCUSSION}

In this paper we examined the flight activity of SPB as a function of maximum daily temperature. Both preliminary statistical analysis and our own judgment indicated maximum daily temperature as the available measurement which best explained patterns of beetle flight. SPB flight is generally concentrated in the late afternoon, which is usually the period of maximum daily temperature. In addition, for the low temperature range, the maximum daily temperature provides a conservative estimate of the temperature at the time of flight. That is, the beetles flew at that temperature or at a lower (more extreme) one. While the appropriate temperature measurement for the high temperature range is not as clearcut, we chose to use maximum daily temperature here as well. It is quite possible, however, the SPB flight in very hot weather takes place before or after the peak temperature is reached. Thus, results for the high temperature should be viewed with some caution.

Flight activity of SPB was measured 2 ways : Number of beetles caught per trap per day (S), and percentage of sample days on which beetles were caught $(P)$. No data analysis was necessary to reject the hypothesis that $14{ }^{\circ} \mathrm{C}$ is the minimum flight temperature for SPB. The data show that they fly at temperatures down to $6.7^{\circ} \mathrm{C}$. In fact, SPB were caught on 15 of the 140 sample days with maximum daily temperatures below $14^{\circ} \mathrm{C}$.

Fitting a regression to $\mathrm{S}(\mathrm{T})$ (Eqn. 1), we projected minimum and maximum flight temperatures of $5.6^{\circ} \mathrm{C}$ and $38.0^{\circ} \mathrm{C}$ (fig. 1). Both projections are consistent with the data, though the upper figure should be viewed with caution, since it is so near the limit of observed temperatures and because of uncertainty of temperature at time of flight. The shape of the curve lends support to the hypothesis that flight declines sharply as the minimum and maximum flight temperatures are approached.

Because the aim of this analysis was estimating flight at extreme temperatures, samples from different sites and different outbreak phases were combined to increase the number of observations. As noted above, this is not problematic for low temperatures. However, the data sets differed significantly between sites and periods over the middle and upper temperature ranges. Separate regressions fitted to each combination of site and outbreak phase gave similar flight temperature projections. But while the shapes of the $\mathrm{S}$ versus temperature regression curves were the same, the absolute numbers varied considerably. Thus, regression equation (1) should not be used to predict SPB flight activity at temperatures above $15{ }^{\circ} \mathrm{C}$. 
The second measure of flight activity, $\mathrm{P}(\mathrm{T})$, was chosen because differences between sites and outbreak phases were much smaller than for $\mathrm{S}(\mathrm{T})$. However, the projections of minimum and maximum flight temperatures were not as satisfactory. In particular, the analysis was complicated by the apparent linearity of $\mathrm{P}$ as a function of $\mathrm{T}$ above the minimum flight temperature (and similarly below the maximum flight temperature - fig. 2). We note nonetheless that using $\mathrm{P}$ as the measure of flight activity tends to refute the hypothesis of precipitous decline in flight activity at extreme temperatures. One possible interpretation is that we are seeing two processes combined here: a pair of sharp flight temperature thresholds for each beetle, and some variation in these thresholds over the population. A test of this idea would require an explicit model and substantial data on behavior of individual SPB, neither of which is presently available.

The observed minimum flight temperature of $6.7^{\circ} \mathrm{C}$ is $7.7^{\circ} \mathrm{C}$ lower than previous estimates of $14.4^{\circ} \mathrm{C}$. In fact, $6.7^{\circ} \mathrm{C}$ is the lowest ever recorded for scolytid flight, the previous minimum being $8{ }^{\circ} \mathrm{C}$ for Blastophagous piniperda (L.) (HEDQvisT, 1965). Hence, SPB belongs to the so-called "early swarmer" group (RUDINSKY, 1962) and is not the "late swarmer" postulated by WHITE \& FRANKLIN (1976). Actually, the terms "early" and "late" swarming are inappropriate for SPB, because it "swarms" the entire year, flying on many "warm" days during winter. Because SPB does not hibernate like its northern relatives, it may have evolved this low temperature flight to exploit its environment during cool weather.

Although our data present a clear picture of SPB cold weather flight activity, the $15,3{ }^{\circ} \mathrm{C}$ discrepancy between our minimum flight temperature of $6.7^{\circ} \mathrm{C}$ and the much higher $22^{\circ} \mathrm{C}$ threshold based on laboratory findings (WHITE \& FRANKLIN, 1976) might have been resolved by accompanying solar insolation, data. While we had no instruments in the field to measure solar insolution, limited visual observations of cloud cover were made at the Alexandria Forestry Center ( 8 and $19 \mathrm{~km}$ from the 2 study areas). Since weather patterns in this region in winter are fairly uniform, the study areas probably had about the same cloud cover as that observed at the Forestry Center. Of the 5 days with temperatures below $9{ }^{\circ} \mathrm{C}$ on which SPB were captured, 3 days were clear or partly cloudy. On those 3 days a significant amount of solar insolation could have warmed the beetles to temperatures well above the air temperature. Of the other 2 days, one was completely overcast and the other received no more than 30 min of sun at noon. Thus, if the solar insolation explanation is valid, only a minimal amount of sunshine may be required to initiate SPB flight.

An alternative hypothesis, that the cold beetles " warm up " by shivering, is discounted by Bernd HEINRICH (Pers. Comm.), who states that any beetle with a body mass less than $5 \mathrm{mg}$ is too small to conserve heat generated in this manner. Average weights for emerging males and females of $D$. frontalis are 2.07 and $2.14 \mathrm{mg}$, respectively (BARRAS \& HODGES, 1974 ; MOSER, 1976). It has been suggested that at low temperatures SPB may not fly, but simply migrate to and attack unattacked portions of the same trees in which they developed (PAYNE, 1980). However, this possibility could not have affected our data since the traps were mounted on wooden stakes, not on trees.

Our observation of SPB peak flight activity at about $27^{\circ} \mathrm{C}$ appears to be within the range for field populations of at least 2 other species of Dendroctonus. ATKINS (1959) and ATKINS \& MCMULLEN (1960) report that the optimum flight temperatures range $22-32{ }^{\circ} \mathrm{C}$ for $D$. pseudotsugae Hopk., and MILLER \& KEEN (1960) record $21.1-29.4{ }^{\circ} \mathrm{C}$ for $D$. brevicomis LeConte. The $32.2-35.0^{\circ} \mathrm{C}$ optimum laboratory figures for $D$. ponderosae Hopk. 1902 cited by MCCAMBRIDGE (1971) are considerably higher than the previous three.

The prediction equations of MOSER \& DELL (1979; 1980) for SPB flight assumed that no reduction in beetle flight occurred at the highest temperature encountered in those studies $\left(33.9^{\circ} \mathrm{C}\right)$. This current study suggests modification of those prediction equations for temperatures above $27^{\circ} \mathrm{C}$, as reduced numbers of beetles can be expected.

Our maximum flight temperature of $36.7^{\circ} \mathrm{C}$ (observed) and $38.0^{\circ} \mathrm{C}$ (projected) is in general agreement with the $35{ }^{\circ} \mathrm{C}$ laboratory maximum for SPB given by White \& FrankLiN (1976). But our maximum observed temperature $\left(36^{\circ} \mathrm{C}\right)$ could possibly be overestimated because many or all of the beetles could have been trapped while the temperature was rising or falling and not at the daily maximum. Our maximum is also in good agreement with field observations of maximum flight temperature for $D$. brevicomis $\left(35.0^{\circ} \mathrm{C}\right)$ (MILLER \& KEEN, 1960) and D. pseudotsugae $\left(38^{\circ} \mathrm{C}\right)$ (ATKINS, 1960 ; ATKINS \& MCMULLEN, 1960), and fair agreement with the $40.6{ }^{\circ} \mathrm{C}$ in laboratory studies of $D$. ponderosae (MCCAMBRIDGE, 1971).

An alternative interpretation of the data for high temperatures is that numbers of adult SPB are actually much lower during periods of peak temperatures (T. DELL, Pers. Comm.). Thus, one could argue that the low numbers of beetles captured on the very hot days was caused by a decline in SPB numbers. Supporting evidence for this view can be found in THATCHER \& PICKARD'S (1964) study. They found attacking beetles dropped below 1:1 during the summer. Unfortunately, we have no such independent estimates of beetle population size for our study.

\section{CONCLUSIONS}

We display here the complete range of temperatures at which the southern pine beetles is known to fly, the first such data for any bark beetle. The optimum flight temperature was estimated to be $27^{\circ} \mathrm{C}$. These findings should serve as a model for determining these parameters for other bark beetles. Flight temperature data are basic to the understanding of bark beetle dispersal, the comprehending of which may be necessary for predicting and managing SPB epidemics. 


\section{ACKNOWLEDGEMENTS}

This research was partially supported by a grant from the USDA Forest Service to W. A. ThOMPSON. We wish to thank J. E. CosTER, R. T. Franklin, B. Heinrich, L. H. MCMullen, and S. L. WOOD for reviewing earlier drafts of this paper and to

F. LIEUTIER for translating selected sections into French.

\section{REFERENCES}

Atkins M. D., 1959. A study of the Douglas-fir beetle, Dendroctonus pseudotsugae Hopk. (Coleoptera : Scolytidae). I. Flight preparation and response. Can. Entomol., 91, 283-291.

Atkins M. D., 1960. A study of the flight of the Douglas-fir beetle Dendroctonus pseudotsugae Hopk. (Coleoptera: Scolytidae). II. Flight movements. Can. Entomol., 92, 941-954.

Atkins M. D., McMullen L. H., 1960. On certain factors influencing Douglas-fir beetle populations. Proc. Fifth World Forestry Congress, p. $857-859$.

Bakke A., 1968. Ecological studies on bark beetles (Coleoptera: Scolytidae) associated with Scots pine (Pinus sylvestris L.) in Norway with particular reference to the influence of temperature. Meddeleser fra Det Norske Skoforsoksvesen, 21, 443-602.

Barras S. J., Hodges J. D., 1974. Weight, moisture, and lipid changes during life cycle of the southern pine beetle. U.S. Dep. Agric. For. Serv. Res. Note SO-178, South. For. Exp. Stn., New Orleans, LA., 5 p.

Franklin R. T., 1970. Southern pine beetle population behavior, $J$. Ga. Entomol. Soc., 5, 175-182.

Geer S. F., Coster J. F., Johnson P. C., 1981. Effects of weather on flight activity of southern pine beetle. J. Ga. Entomol. Soc., 16, 272-282.

Hedqvist K.-J., 1965. Studier over for virkesvarden viktiga barkborrar langs Umealv. Skogshogskolan Inst. Virkeslara. Rapp. Upps., R 51, 1-23.

Kinn D. N., 1978. Duel emergence patterns of the southern pine beetle (Dendroctonus frontalis Zimm.). J. Ga. Entomol. Soc., 13, 80-85.

McCambridge W. F., 1971. Temperature limits of flight of the mountain pine beetle, Dendroctonus ponderosae. Ann. Entomol. Soc. Am., 64, 534-535.
Miller J. M., Keen F. P., 1960. Biology and control of the western pine beetle. U.S. Dep. Agric. Misc. Publ., 800, 381 p.

Moser J. C., 1976. Phoretic carrying capacity of flying southern pine beetles (Coleoptera : Scolytidae). Can. Entomol., 108, 807808 .

Moser J. C., Browne L. E., 1978. A nondestructive trap for Dendroctonus frontalis Zimmermann (Coleoptera : Scolytidae). J. chem. Ecol., 4, 1-7.

Moser J. C., Dell T. R., 1979. Predictors of southern pine beetle flight activity. For Sci., 25, 217-222.

Moser J. C., Dell T. R., 1980. Weather factors predicting flying populations of a clerid predator and its prey, the southern pine beetle, p. 266-278. In A. A. Berryman and L. Safranyik |eds.|, Dispersal of forest insects: evaluation, theorv, and management implications, Proceedings of the Second IUFRO Conference, Sandpoint, ID., Cooperative Extension Service, Washington State University, Pullman, WA., 278 p.

Payne T. L., 1980. Life history and habits, p. 7-28. In R. C. Thatcher, J. L. Searcy, J. E. Coster, and G. D. Hertel [eds.]. The southern pine beetle, U.S. Dep. Agric. For. Serv. Sci. and Tech. Admin. Tech. Bull., 1631, 266 p.

Rudinsky J. A., 1962. Ecology of Scolytidae, p. 327-348. In E. A. Steinhaus and R. F. Smith [eds.l. Annual review of entomology, Entomol. Soc. Am., College Park, MD. 536 p.

Thatcher R. C., 1967. Winter brood development of the southern pine beetle in Southeast Texas. J. econ. Entomol., 60, 599-600.

Thatcher R. C., Pickard L. S., 1964. Seasonal variations in activity of the southern pine beetle in East Texas. J. econ. Entomol, 57, $840-842$.

White R. A. Jr., Franklin R. T., 1976. Activity of the southern pine beetle in response to temperature. J. Ga. Entomol. Soc., 11, 370-372. 